\title{
Absolute Poverty of Early Childhood Children: A Comparative Analysis of Java and Non-Java
}

\author{
Lucie Suparintina ${ }^{1^{*}}$, Bambang Eko Afiatno ${ }^{2}$ \\ ${ }^{*}$ Corresponding author
}

\begin{abstract}
The development of quality human resources in the future depends on the development of children today. Deprived children's basic needs, such as preschool education, protection, health, and nutrition, make it difficult for children to be free from poverty. This study aims to analyze the determinants of early childhood children aged 3-6 years old who suffer from absolute poverty in Java, Bali-Nusa Tenggara, and MalukuPapua using logistic regression. The results showed that the majority of early childhood children in Java deprive in 1 dimension. However, in the other regions, the majority of them are deprived in 2 dimensions. The education level of both the household head and the mother and the residential area had a significant effect on the possibility of an absolute poverty early childhood children in all regions. Government programs such as 12-year required education, agricultural business capital, and infrastructure development in rural areas need to be improved further.
\end{abstract}

Keywords: absolute child poverty, early childhood children, preschool education, health, nutrition

\begin{abstract}
Abstrak
Pembangunan sumber daya manusia berkualitas di masa mendatang bergantung pada pembangunan anak-anak saat ini. Kebutuhan dasar anak usia dini seperti pendidikan prasekolah, perlindungan, kesehatan, dan nutrisi yang tidak terpenubi menyebabkan anak sulit terbebas dari kemiskinan. Penelitian ini bertujuan untuk menganalisis determinan anak usia dini berusia 3-6 tabun mengalami miskin absolut di tiga kelompok wilayah di Indonesia yaitu Jawa, Bali-Nusa Tenggara, dan Maluku-Papua dengan menggunakan regresi logistik. Hasil penelitian menunjukkan bahwa mayoritas anak usia dini di Jawa terdeprivasi pada 1 dimensi, sedangkan di Bali-Nusa Tenggara dan Maluku-Papua mayoritas anak usia dini terdeprivasi pada 2 dimensi. Pendidikan kepala rumah tangga, pendidikan ibu, dan daerah tempat tinggal berpengaruh signifikan terhadap peluang anak usia dini miskin absolut di ketiga wilayah. Program pemerintah seperti wajib belajar 12 tahun, modal usaha pertanian untuk petani, dan pembangunan infrastruktur di desa perlu ditingkatkan kembali.
\end{abstract}

Kata Kunci: kemiskinan anak absolut, anak usia dini, pendidikan prasekolah, kesehatan, nutrisi JEL Classification: I15, I25, I32

\section{How to Cite:}

Suparintina, L., \& Afiatno, B. E. (2020). Absolute Poverty of Early Childhood Children: a Comparative Analysis of Java and Non-Java. Signifikan: Jurnal Ilmu Ekonomi, Vol. 9(1), 107-122. doi: http://dx.doi.org/10.15408/sjie. v9i1.14056. 


\section{Introduction}

Poverty has become one big problem in Indonesia. The complicated causes of poverty result in difficulty in overcoming the problem. One of the agreed programs in the National Medium-Term Development Plan (RPJMN) is to make efforts to reduce poverty, as stated in one of the objectives of the Sustainable Development Goals (SDGs). SDGs are a continuation and expansion of the Millennium Development Goals (MDGs) that have been established by the United Nations and implemented by countries in the world since 2001. The first goal of SDGs is to end all forms of poverty everywhere.

Poverty is recognized as a multidimensional phenomenon and emphasizes the critical role of national social protection systems. These goals can be pursued through strategic policies, namely increasing economic growth, increasing access to essential services (such as education, health, clean water, and sanitation), and beneficial government expenditure policies. Poverty is not only experienced by adults but also by children. This condition is because children have a higher risk of experiencing poverty; children are very dependent on the people around them in satisfying their basic needs (Roelen \& Neubourg, 2009). Most children in developing countries are in poverty (SMERU, 2013). Based on Act no 35, 2014, a child is someone who ages under 18 years old, including an unborn human baby.

The number of children aged 0-17 years old in 2010 was around 81.1 million people, and the number has continued to increase until 2020, which is around 84.15 million people. An increase of children aged 0-17 years old without concurring attempts to fulfill the children's basic needs as their life's provisions will result in development burdens in the future. Poverty will inhibit children's optimal growth and development. This condition will cause difficulty in developing quality human resources (Sukamti, 1994). The percentage of child poverty using the monetary approach (per capita expenditure) in Indonesia is 13.31 percent. The percentage of child poverty in the Maluku-Papua region (27.23 percent), Bali-Nusa Tenggara (18.93 percent), and Java (11.96 percent). However, the child poverty share in each region is Java (47.39 percent), Bali-Nusa Tenggara (8.67 percent), and Maluku-Papua (6.52 percent).

Roelen \& Neubourg (2009) said that child poverty is not enough to be measured only by a monetary approach (household income), requiring complex data covering many factors, especially those that affect the physical, emotional, and mental development of children. Gordon et al. (2003), a monetary approach to measuring child poverty, is not ideal for developing countries because poverty analysis based on household income or expenditure usually assumes the equal distribution of resources within households. As a result, the determination of policies in the alleviation of child poverty is almost always not on target.

The best approach in measuring poverty is to use a deprivation approach, which is a condition of lack of something considered important for welfare. In this approach, measuring poverty is not only using indicators of household income or expenditure, but also by using various other dimensions that reflect actual poverty, such as limited access to clean water, sanitation, education, health, and birth registration (Alkire, 2015). The results of poverty measurement with a multidimensional approach can illustrate poverty better when compared to the household income or expenditure approach (Dickerson \& Popli, 2017). 
Brooks-Gunn \& Duncan (1997), suggested that children who experience poverty in preschool (early childhood) will tend to lower the education they have. As a result, children will have difficulty getting decent work so that government efforts in breaking the chain of poverty hamper. The best strategy for solving long-term poverty problems is through human development from the age of children. Efforts in alleviating child poverty through programs that tend to equalize poverty become less appropriate, so it is necessary to formulate policies that can target child poverty. Accurate and comprehensive data on child poverty needs to be owned by the government to use as a basis for formulating various policies on reducing child poverty (Fox et al., 2015).

Generally, poor children live in low-income families, so that to alleviate child poverty can do by freeing their families from the snares of poverty (Chou, 2013). Household characteristics factors can affect the chances of a poor child, especially related to the ability of parents to meet the needs of children, both materially and non-materially (Ramadhani, 2017). Previous studies of child poverty in Indonesia were carried out only in the province (Bachtiar, et al., 2016; Ramadhani, 2017). In this study, coverage expands by comparing three regions in Indonesia, namely Java, Bali-Nusa Tenggara, and Maluku-Papua. The early childhood children aged 3-6 years old are objects to be studied. Therefore, policies set by the government can adjust to the conditions of each region. Provinces and regions have contributed to reducing national poverty (Qi \& Wu, 2015).

There are three thoughts on poverty produced by the school of thought. First, the welfare school is the view of poverty in terms of welfare. This view sees poverty as a condition of society's inability to achieve a certain level of welfare. The right solution to this problem is to increase economic growth. Second, the primary need school is the view of poverty in terms of basic needs. According to this view, poverty occurs when people are unable to meet their basic needs, such as food, water, sanitation, shelter, education, and health. Third, the capability of school is the view of poverty in terms of capabilities. According to this view, poverty occurs when people have deficient capabilities resulting in low competing capabilities in the labor market (Ifelunini et al., 2013).

Child poverty is a description of deprived basic needs and violations against children's rights (Pemberton et al., 2012; Musiwa, 2019). Child poverty with an approach to the basic needs of children is considered the best way to find out the description of poverty. The approach to children's fundamental rights is essential for interventions of policy and social welfare, especially in developing regions or countries. This policy will provide a standard measure that can be universally shared to determine the deprivation of children's rights caused by poverty (Pemberton et al., 2012). Brooks-Gunn \& Duncan (1997) stated that grouping children could do child poverty into five age groups such as prenatal/newborns up to 2 years, early childhood (3-6 years), late childhood (7- 12 years), early adolescence (11-15 years), and late adolescence (16-19 years).

Age grouping in studies on child poverty usually bases on the needs of each age group of children according to the transition period and their life development. At an early childhood phase, children have been able to perform a variety of language, physical, and self- 
confidence skills in exploring their independence (Hurlock in Rochwidowati \& Widyana, 2017). Therefore, the basic rights of children should not be deprived.

Therefore, the basic rights of children should not deprive.

Based on the two considerations, this study focus on examining groups of early childhood children (3-6 years). Within this age range, children's brain develops up to 80 percent, so fulfilling their basic needs is considered very important. Besides, children who suffer from poverty at early childhood (preschool age) will be more vulnerable to poverty in adulthood (Brooks-Gunn \& Duncan, 1997).

Table 1. Dimensions, Indicators, and Concepts of Severe Deprivation in Early Childhood Children

\begin{tabular}{|c|c|c|}
\hline Dimensions & Indicators & Concepts of Severe Deprivation \\
\hline Education & School participation & $\begin{array}{l}\text { Children aged 3-6 years do not attend preschool } \\
\text { education. }\end{array}$ \\
\hline Health & Health insurance & Children aged 3-6 years do not have health insurance. \\
\hline Protection & Certificate of birth & Children aged 3-6 years do not have birth certificates. \\
\hline Nutrition & Calorie consumption & $\begin{array}{l}\text { Children aged } 3-6 \text { years consume fewer calories than } \\
\text { MDER (Minimum Dietary Energy requirements); a } \\
\text { minimum of } 1125 \text { kilocalorie per day for children aged } \\
3 \text { years and } 1600 \text { kilocalorie per day for children aged } \\
4-6 \text { years. }\end{array}$ \\
\hline
\end{tabular}

Source: Gordon et al., 2003: 8 (modified according to data availability)

* Based on Minister of Health Regulation No. 75 of 2013

The concept of deprivation and poverty describes the condition of a person suffering from a lack of basic needs in a variety of conditions, not just depending on income (Gordon et al., 2005). The concept of deprivation in poverty can also be called multidimensional poverty. Measurement of absolute poverty in children is needed to define measures of the threshold for severe deprivation of basic needs such as food, drinking water, sanitation, education, health, and protection (Gordon et al., 2005; Roelen \& Neubourg, 2009). In a recent study, the Bristol Approach use through a deprivation approach to basic rights related to child poverty and child rights (Gordon et. al., 2003). This method has been used in measuring the number of poor children in developing countries.

The selection of basic needs dimensions and indicators in this study base on several considerations. The considerations are a literature review that refers to the Act of Child Protection, 3-6 years age group (early childhood children), as well as the availability of data and variables in the Susenas questionnaire that has adjusted to the targets of RPJMN and SDGs. In summary, the selected dimensions and indicators are shown in Table 1. (Gordon et al., 2005) have stated that a child lives in absolute poverty or multidimensional poverty only if the child suffers from various deprivations (deprived in two or more dimensions of basic needs).

This research wants to focus on the dimensions of basic early childhood children's needs, such as nutrition, preschool education, protection, and health insurance. This study 
aims to analyze the determinants of early childhood children aged 3-6 years old who suffer from absolute poverty in Java, Bali-Nusa Tenggara, and Maluku-Papua. Furthermore, this research will present an analysis of poverty in early childhood children in Java, Bali-Nusa Tenggara, and Maluku-Papua through a multidimensional (deprivation) approach. Besides, it will also show the relationship between household characteristics factors to the possibility of early childhood children suffering absolute poverty.

\section{Methode}

The data used in this study are raw data from the results of the March 2018 National Socioeconomic Survey (Susenas). The observation units are early childhood children aged 3-6 years from three regional groups in Indonesia. Those regions are Java, Bali-Nusa Tenggara, and Maluku-Papua. The number of samples obtained from March 2018 Susenas in each region is as follows Java (19,326 children), Bali-Nusa Tenggara (6,433 children), and Maluku-Papua (8,660 children).

The results of the calculation of child poverty data with the deprivation approach (multidimensional poverty) descriptively analyze by displaying graphs or figures. Meanwhile, in order to see the relationship between household characteristics and the possibility of early childhood children suffering from absolute poverty, it will inferentially be analyzed using logistic regression analysis. In this study, the categories used are $Y=1$ for absolute poor child status and $\mathrm{Y}=0$ for non-poor child status.

Agresti (2007) states that logistic regression analysis is a method that figures out the relationship between response variables (dependent), which are binary (dichotomous) with several predictor variables (independent), which are polychotomous. The logistic regression model can be used to see the probability of a particular event by considering various factors that influence it, as well as comparing the risk of the emergence of a situation as a result of a factor after considering other factors in the model (Hosmer \& Lemeshow, 1991).

For example, when the response variable is $y$ and the predictor variable is $x$, based on the Bernoulli Distribution the probability function is obtained as follows:

$$
f(y)=\pi^{y}(1-\pi)^{1-\mathrm{y}}, y=0 \text { or } 1
$$

Equation (1) shows that the response variable $y$ is categorical. The logistical functions of the response variable $y$ and the predictor variable $x$ are:

$$
f(x)=y=\frac{1}{1+e^{-x}}, 0<x<1
$$

Equation (2) shows that the value of $f(x)$ ranges from 0 to 1 . In this study, the categories used are $(Y=1)$ for absolute poor child status and $(Y=0)$ for non-poor child status.

The value of $\mathrm{x}$ in equation (2) illustrates the effect that causes absolute poor children starting from the minimum limit of 0 to nearly 1 . The form of the logistic regression model obtained is as follows:

$$
\pi(x)=\frac{\exp \left(\beta_{0}+\beta_{1} x_{1}+\beta_{2} x_{2}+\cdots+\beta_{p} x_{p}\right)}{1+\exp \left(\beta_{0}+\beta_{1} x_{1}+\beta_{2} x_{2}+\cdots+\beta_{p} x_{p}\right)}
$$

Next, logit transformation is carried out to equation (3) with p predictor variables in order to estimate the regression parameters as follows: 


$$
g(x)=\beta_{0}+\beta_{1} x_{1}+\beta_{2} x_{2}+\cdots+\beta_{p} x_{p}
$$

Based on equation (4), it shows that the logistic regression model has become a linear function of its parameters. This study uses data from three different regions so that the three research models are:

$$
g(x)=P=\beta_{0}+\beta_{1} V_{1}+\beta_{2} V_{2}+\beta_{3} V_{3}+\beta_{4} V_{4}+\beta_{5} V_{5}
$$

Information about dummy variables and the categories of each variable can be seen in Table 2:

\begin{tabular}{|c|c|c|}
\hline Variable Name & Variable Information & Dummy Category \\
\hline$P$ & Absolute Child Poverty Status & $\begin{array}{l}1=\text { Absolute Poverty } \\
0=\text { Not poor }\end{array}$ \\
\hline V1 & Household Head's Education & $\begin{array}{l}1=\leq \text { Junior high school or equivalent } \\
0=>\text { Junior high school or equivalent }\end{array}$ \\
\hline V2 & Mother's Education & $\begin{array}{l}1=\leq \text { Junior high school or equivalent } \\
0=>\text { Junior high school or equivalent }\end{array}$ \\
\hline V3 & Household Head's Business Sector & $\begin{array}{l}1=\text { Agriculture } \\
0=\text { Non-agriculture }\end{array}$ \\
\hline V4 & Number of Household Members & $\begin{array}{l}1=>4 \text { people } \\
0=\leq 4 \text { people }\end{array}$ \\
\hline V5 & Residential Area & $\begin{array}{l}1=\text { Rural } \\
0=\text { Urban }\end{array}$ \\
\hline
\end{tabular}

Table 2. Constructing Variables in Logistic Regression

\section{Result and Discussion}

\section{Absolute Poverty of Early Childhood Children in Java and Non-Java}

Based on the results of Susenas March 2018, the data have shown that the percentage of early childhood children whose four dimensions of basic rights have already fulfill is 26.35 percent (Java), 14.85 percent (Bali-Nusa Tenggara), and 7.97 percent (Maluku-Papua). It means that both in Java and Non-Java regions, there are still early childhood children whose basic rights have not been fulfilled yet (deprived). Based on these results, it can state that early childhood children are vulnerable to suffering from absolute poverty.

In Table 3, it can show that the majority of early childhood children in the Java region is deprived in 1 dimension, amounting to 7,969 children ( 41.23 percent). In contrast to the other two regions, most of the early childhood children in Bali-Nusa Tenggara and MalukuPapua deprive in 2 dimensions, respectively 2,048 children (31.83 percent) and 3,310 children (38.22 percent). Thus, looking at the definition of absolute child poverty then it can be argued that Bali-Nusa Tenggara and Maluku-Papua regions have a higher number of young children suffering from absolute poverty than the Java region. 
Table 3. Deprived Early Childhood Children In Java, Bali-Nusa Tenggara, and Maluku-Papua

\begin{tabular}{|c|c|c|c|c|c|c|}
\hline \multirow{3}{*}{$\begin{array}{l}\text { Number of } \\
\text { deprived } \\
\text { dimensions }\end{array}$} & \multicolumn{6}{|c|}{ Region } \\
\hline & \multicolumn{2}{|c|}{ Java } & \multicolumn{2}{|c|}{ Bali-Nusa Tenggara } & \multicolumn{2}{|c|}{ Maluku-Papua } \\
\hline & $\begin{array}{l}\text { Number } \\
\text { of Early } \\
\text { Childhood }\end{array}$ & Percentage & $\begin{array}{l}\text { Number } \\
\text { of Early } \\
\text { Childhood }\end{array}$ & Percentage & $\begin{array}{l}\text { Number } \\
\text { of Early } \\
\text { Childhood }\end{array}$ & Percentage \\
\hline 0 Dimension & 5,093 & $26.35 \%$ & 956 & $14.86 \%$ & 690 & $7.97 \%$ \\
\hline 1 Dimension & 7,969 & $41.23 \%$ & 2,018 & $31.36 \%$ & 1,846 & $21.31 \%$ \\
\hline 2 Dimension & 4,817 & $24.92 \%$ & 2,048 & $31.83 \%$ & 3,310 & $38.22 \%$ \\
\hline 3 Dimension & 1,342 & $6.95 \%$ & 1,207 & $18.76 \%$ & 2,308 & $26.65 \%$ \\
\hline 4 Dimension & 105 & $0.54 \%$ & 207 & $3.22 \%$ & 506 & $5.84 \%$ \\
\hline
\end{tabular}

Source: Susenas March 2018, Statistics of Indonesia (Author's calculation)

Furthermore, the results of the number of calculations of early childhood children suffering from absolute poverty can show in Figure 1. The Figure 1 shows that the highest absolute poverty of early childhood is in Maluku-Papua regions, and the lowest is in Java regions.

Figure 1. Percentage of Absolute Poverty of Early Childhood Children in Java, Bali-Nusa Tenggara, and Maluku-Papua

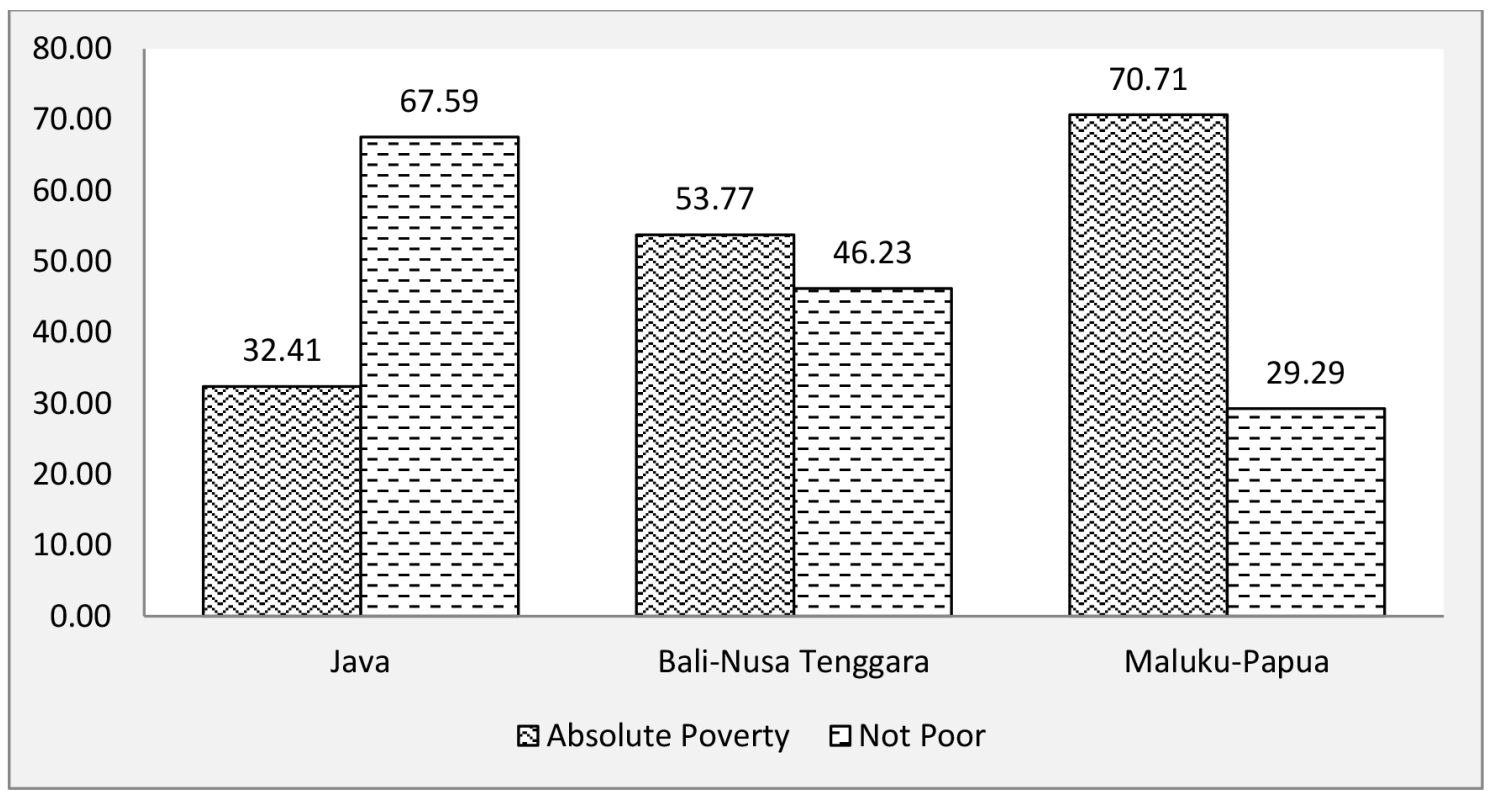

Source: Susenas March 2018, Statistics of Indonesia (Author's calculation)

The previous chapter has explained that children will suffer from absolute poverty only if their basic rights deprived in at least two dimensions. From the figure, it can be seen that the highest percentage of absolute childhood poverty occurs in Maluku-Papua Island by 70.71 percent. The Java region has the lowest percentage of early childhood children suffering from absolute poverty at 32.41 percent. As a result, the government needs to prioritize the Maluku-Papua region in poverty reduction programs following the basic rights of the deprived children. 
Figure 2. Percentage of Early Childhood Children Deprivation in Each Dimensions in Java, Bali-Nusa Tenggara, and Maluku-Papua

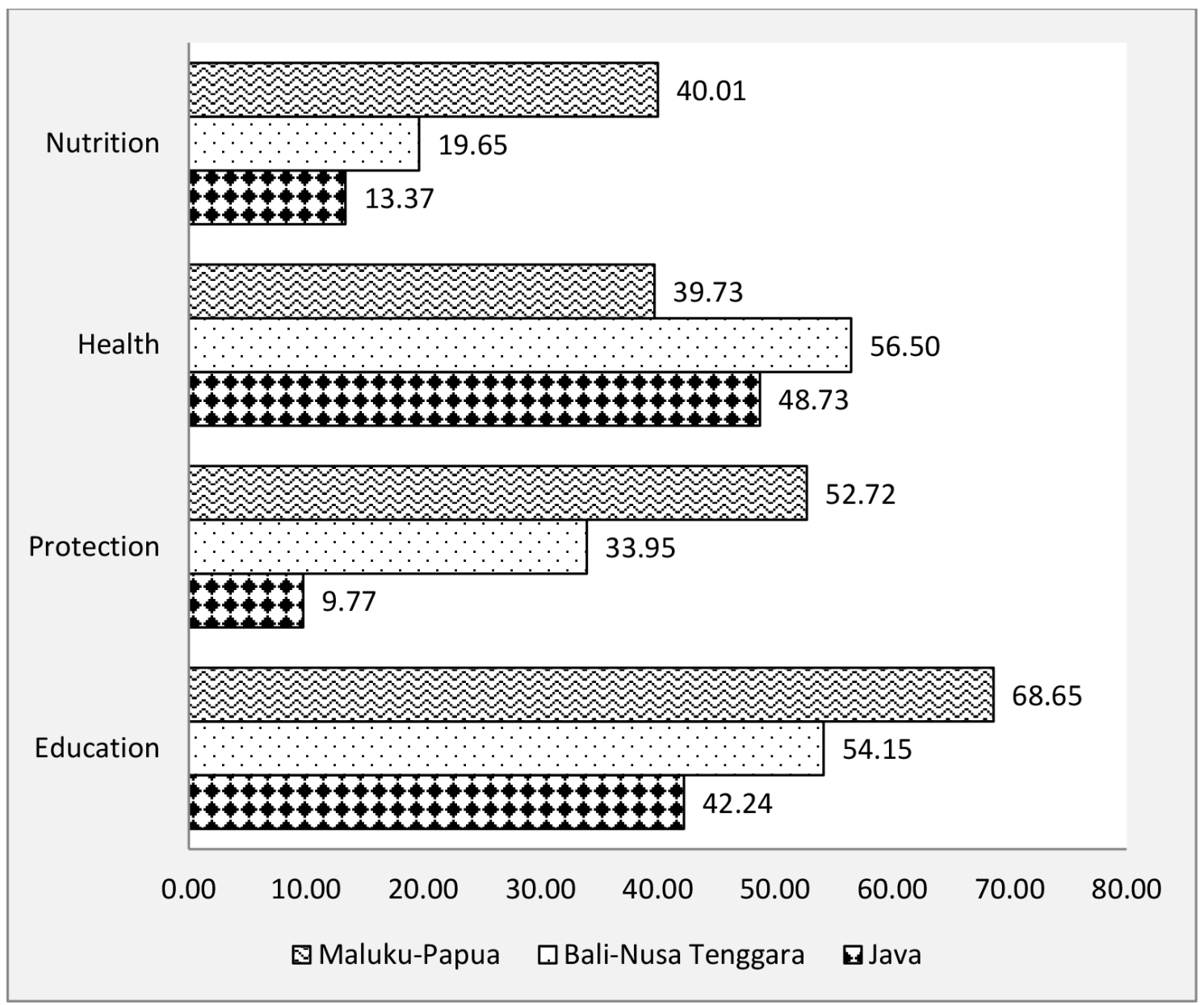

Source: Susenas March 2018, Statistics of Indonesia

Regarding the efforts made in fulfilling the basic rights of children, each region has a similarity in terms of the order of dimensions of deprived children's basic rights. Figure 2 shows that in Java and Bali-Nusa Tenggara, early childhood children, most deprive of the health dimension. This result means that ownership of health insurance for early childhood children in Java and Bali-Nusa Tenggara is still very low, with a percentage of 48.73 percent and 56.50 percent, respectively. Health insurance is essential for everyone who lives in Indonesia (including early childhood children) because it can guarantee that they get health services in the area where they live. Meanwhile, in Maluku-Papua, many early childhood children are deprived of the educational dimension. This result shows that in Maluku-Papua, early childhood children's participation in preschool education is still very low. The government needs to equalize early childhood children development in Maluku-Papua so that there are no gaps in the quality of human resources in every region in Indonesia. The protection dimension (birth certificate ownership) is the basic rights of the least deprived children in the Java region. This result is consistent with previous research indicating that the basic rights of children under five in West Sumatra having the highest achievement rate of fulfillment is a birth certificate (Bachtiar et al., 2016). However, between regional groups, it can be seen that there remains a wide gap between 
Java and Bali-Nusa Tenggara as well as Maluku-Papua in terms of birth certificate fulfillment for children. Consequently, this issue needs attention from the relevant local government.

The percentage of deprived children in the nutrition dimension is relatively low when compared to other dimensions, although in Maluku-Papua, it is still relatively high when compared to Java and Bali-Nusa Tenggara. This condition means that the calorie need per day of early childhood children has fulfilled.

Overall, Java is the best regional group in fulfillment of the basic rights of children when compared to the other two regions. However, Java Island has a high percentage of deprived early childhood children in the dimension of education (42.24 percent) and health (48.75 percent). This condition deserves equal government attention because Java is an area that uses as a measure of the quality of human resources in Indonesia.

Based on Table 3, it can observe that the percentage of children's basic needs that are satisfied by household characteristics in each region. In Java, almost all dimensions of basic needs for early childhood children are satisfied with a higher percentage compared to other regions. Basic needs such as health insurance are the highest percentage in Maluku-Papua compared to Java and Bali-Nusa Tenggara. However, the highest number is found in Java because the number of samples of early childhood children in Java is the most compared to other regions.

In all three regions, the percentage of parents of young children with junior high school education and below was higher than the parents of young children who educate above the junior secondary school. This condition needs to be a concern because the role of education in fulfilling the basic needs of children is crucial. The higher the education of parents, the easier it will be to get access to information such as education, health, and protection for children to realize a better future. Household head's education influences the possibility of children suffering from poverty (Bachtiar et al., 2016; Ramadhani, 2017).

The percentage of the heads of households business sector of early childhood children in the agricultural sector is lower than the heads of households who work outside of the agricultural sector. These conditions find in Java, Bali-Nusa Tenggara, and parts of Maluku-Papua. This means that in the three regions, the basic needs of early childhood children satisfied with heads of households who work outside of the agricultural sector and early childhood children who have heads of households working in the agricultural sector are different. Households that have household heads working in the agricultural sector will tend to be in a condition of restricted economics condition. The economic inability of the household head will influence the fulfillment of the basic needs of children living in the household. Thus, the children will force to sacrifice their childhood to work to help parents make a living.

In Java, the number of household members of 4 people or less has a higher percentage than households with more than four members. Meanwhile, in Bali-Nusa Tenggara and Maluku-Papua, the opposite applies. However, this shows that the basic needs of early childhood children satisfied by considering the number of household members in the three regions are different. A household considers the number of household members in fulfilling their daily needs. The more the number of household members, the more substantial the burden of dependents in the household (Ferrone \& Chzhen, 2016). 
Table 4. Percentage of Basic Needs Satisfied Based on Household Characteristics in Java and Non-Java

\begin{tabular}{|c|c|c|c|c|}
\hline & \multicolumn{4}{|c|}{ Basic Needs of Early Childhood Children } \\
\hline & $\begin{array}{l}\text { Preschool } \\
\text { Education }\end{array}$ & $\begin{array}{c}\text { Certificate of } \\
\text { Birth }\end{array}$ & $\begin{array}{c}\text { Health } \\
\text { Insurance }\end{array}$ & $\begin{array}{c}\text { Calories } \\
\text { Consumption }\end{array}$ \\
\hline Java & $57.76 \%$ & $90.23 \%$ & $51.27 \%$ & $86.63 \%$ \\
\hline \multicolumn{5}{|l|}{ Household Head's Education } \\
\hline$\leq \mathrm{JHS}$ or equivalent & $33.88 \%$ & $53.11 \%$ & $25.62 \%$ & $53.42 \%$ \\
\hline$>\mathrm{JHS}$ or equivalent & $23.88 \%$ & $37.12 \%$ & $25.65 \%$ & $33.21 \%$ \\
\hline \multicolumn{5}{|l|}{ Mother's Education } \\
\hline$\leq \mathrm{JHS}$ or equivalent & $35.54 \%$ & $56.64 \%$ & $28.10 \%$ & $56.77 \%$ \\
\hline$>$ JHS or equivalent & $22.22 \%$ & $33.58 \%$ & $23.17 \%$ & $29.86 \%$ \\
\hline \multicolumn{5}{|c|}{ Household Head's Business Sector } \\
\hline Agriculture & $15.04 \%$ & $22.96 \%$ & $11.18 \%$ & $23.37 \%$ \\
\hline Non-agriculture & $42.72 \%$ & $67.26 \%$ & $40.09 \%$ & $63.26 \%$ \\
\hline \multicolumn{5}{|l|}{ Number of Household Members } \\
\hline$>4$ people & $24.06 \%$ & $37.94 \%$ & $22.23 \%$ & $35.54 \%$ \\
\hline$\leq 4$ people & $33.70 \%$ & $52.28 \%$ & $29.04 \%$ & $51.09 \%$ \\
\hline \multicolumn{5}{|l|}{ Residential Area } \\
\hline Rural & $22.08 \%$ & $33.64 \%$ & $15.44 \%$ & $34.80 \%$ \\
\hline Urban & $35.68 \%$ & $56.58 \%$ & $35.83 \%$ & $51.83 \%$ \\
\hline Bali-Nusa Tenggara & $45.85 \%$ & $66.05 \%$ & $43.50 \%$ & $80.35 \%$ \\
\hline \multicolumn{5}{|l|}{ Household Head's Education } \\
\hline$\leq \mathrm{JHS}$ or equivalent & $28.04 \%$ & $38.90 \%$ & $25.13 \%$ & $51.32 \%$ \\
\hline$>\mathrm{JHS}$ or equivalent & $17.81 \%$ & $27.15 \%$ & $18.37 \%$ & $29.03 \%$ \\
\hline \multicolumn{5}{|l|}{ Mother's Education } \\
\hline$\leq \mathrm{JHS}$ or equivalent & $29.83 \%$ & $42.24 \%$ & $27.35 \%$ & $55.10 \%$ \\
\hline$>$ JHS or equivalent & $16.02 \%$ & $23.81 \%$ & $16.15 \%$ & $25.25 \%$ \\
\hline \multicolumn{5}{|c|}{ Household Head's Business Sector } \\
\hline Agriculture & $22.29 \%$ & $28.01 \%$ & $19.51 \%$ & $38.76 \%$ \\
\hline Non-agriculture & $23.56 \%$ & $38.05 \%$ & $23.99 \%$ & $41.59 \%$ \\
\hline \multicolumn{5}{|l|}{ Number of Household Members } \\
\hline$>4$ people & $28.36 \%$ & $39.70 \%$ & $28.51 \%$ & $48.30 \%$ \\
\hline$\leq 4$ people & $17.49 \%$ & $26.35 \%$ & $14.99 \%$ & $32.05 \%$ \\
\hline \multicolumn{5}{|l|}{ Residential Area } \\
\hline Rural & $31.78 \%$ & $40.33 \%$ & $27.37 \%$ & $54.20 \%$ \\
\hline Urban & $14.07 \%$ & $25.72 \%$ & $16.13 \%$ & $26.15 \%$ \\
\hline Maluku-Papua & $31.35 \%$ & $47.28 \%$ & $60.27 \%$ & $59.99 \%$ \\
\hline \multicolumn{5}{|l|}{ Household Head's Education } \\
\hline$\leq \mathrm{JHS}$ or equivalent & $16.40 \%$ & $21.96 \%$ & $37.42 \%$ & $35.45 \%$ \\
\hline$>\mathrm{JHS}$ or equivalent & $14.95 \%$ & $25.32 \%$ & $22.85 \%$ & $24.54 \%$ \\
\hline \multicolumn{5}{|l|}{ Mother's Education } \\
\hline$\leq \mathrm{JHS}$ or equivalent & $18.75 \%$ & $25.94 \%$ & $43.97 \%$ & $40.82 \%$ \\
\hline$>$ JHS or equivalent & $12.60 \%$ & $21.34 \%$ & $16.30 \%$ & $19.18 \%$ \\
\hline \multicolumn{5}{|c|}{ Household Head's Business Sector } \\
\hline Agriculture & $14.46 \%$ & $18.29 \%$ & $37.19 \%$ & $32.93 \%$ \\
\hline Non-agriculture & $16.89 \%$ & $28.99 \%$ & $23.08 \%$ & $27.06 \%$ \\
\hline \multicolumn{5}{|l|}{ Number of Household Members } \\
\hline$>4$ people & $21.63 \%$ & $31.82 \%$ & $42.10 \%$ & $38.18 \%$ \\
\hline$\leq 4$ people & $9.72 \%$ & $15.46 \%$ & $18.17 \%$ & $21.81 \%$ \\
\hline \multicolumn{5}{|l|}{ Residential Area } \\
\hline Rural & $22.80 \%$ & $29.96 \%$ & $48.50 \%$ & $45.30 \%$ \\
\hline Urban & $8.55 \%$ & $17.32 \%$ & $11.77 \%$ & $14.69 \%$ \\
\hline
\end{tabular}

Source: Susenas March 2018, Statistics of Indonesia (Author's calculation)

The same results show in the residential area, the number of early childhood children in Java who live in urban areas more than in rural areas. This can be caused by the fact that development in Java is more equitable compared to other regions so that access from the residence to the center of government is relatively easy. Also, poverty can cause by the low quality of human resources and natural resources. Based on these two perceptions, it can conclude that the farther the location of the village from the center of government, the higher 
the possibility of a person suffering from poverty due to limited resources. In Bali-Nusa Tenggara and Maluku-Papua, the majority of early childhood living in rural households. This condition causes efforts to satisfy the basic needs of early childhood children stunted.

\section{Absolute Poverty of Early Childhood Children and Household Characteristics}

Binary logistic regression is using to analyze the relationship between household characteristics and the possibility of early childhood children suffering from absolute poverty. In simultaneous testing (overall test), it shows that the research model is suitable for analyzing the three regions. The results of data processing on the relationship of household characteristics with the possibility of early childhood children suffering from absolute poverty in each region can observe in Table 5. Furthermore, the results of the goodness of fit test can show in the Hosmer, and Lemeshow test p-values obtained from each region group are Java (0.818), BaliNusa Tenggara (0.117), and Maluku-Papua (0.379).

Table 5. Logistic Regression Output in Java, Bali-Nusa Tenggara, and Maluku-Papua

\begin{tabular}{|c|c|c|c|c|c|c|c|c|c|}
\hline \multirow[t]{2}{*}{ Variables } & \multicolumn{3}{|c|}{ Java } & \multicolumn{3}{|c|}{ Bali-Nusa Tenggara } & \multicolumn{3}{|c|}{ Maluku-Papua } \\
\hline & $\begin{array}{l}\text { Coef. } \\
\text { Std Err }\end{array}$ & $\begin{array}{l}\text { Odds } \\
\text { Ratio }\end{array}$ & $P>|z|$ & $\begin{array}{l}\text { Coef. } \\
\text { Std Err }\end{array}$ & $\begin{array}{l}\text { Odds } \\
\text { Ratio }\end{array}$ & $P>|z|$ & $\begin{array}{l}\text { Coef. } \\
\text { Std Err }\end{array}$ & $\begin{array}{l}\text { Odds } \\
\text { Ratio }\end{array}$ & $P>|z|$ \\
\hline Const. & $\begin{array}{c}-1.557^{* *} \\
(0,348)\end{array}$ & 0.211 & 0.000 & $\begin{array}{c}-0.080^{* *} \\
(0.067)\end{array}$ & 0.339 & 0.000 & $\begin{array}{c}-0.703^{* *} \\
(0.064)\end{array}$ & 0.495 & 0.000 \\
\hline $\begin{array}{l}\text { Household Head's } \\
\text { Education (V1) }\end{array}$ & $\begin{array}{l}0.415^{* *} \\
(0.042)\end{array}$ & 1.514 & 0.000 & $\begin{array}{l}0.397^{* *} \\
(0.064)\end{array}$ & 1.487 & 0.000 & $\begin{array}{l}0.410^{* *} \\
(0.062)\end{array}$ & 1.507 & 0.000 \\
\hline $\begin{array}{l}\text { Mother's Education } \\
\text { (V2) }\end{array}$ & $\begin{array}{l}0.511^{* *} \\
(0.044)\end{array}$ & 1.667 & 0.000 & $\begin{array}{l}0.521^{* *} \\
(0.065)\end{array}$ & 1.684 & 0.000 & $\begin{array}{l}0.705^{* *} \\
(0.064)\end{array}$ & 2.025 & 0.000 \\
\hline $\begin{array}{l}\text { Household Head's } \\
\text { Business Sector } \\
\text { (V3) }\end{array}$ & $\begin{array}{l}-0.016 \\
(0.037)\end{array}$ & 0.017 & 0.655 & $\begin{array}{l}0.357^{* *} \\
(0.060)\end{array}$ & 1.429 & 0.000 & $\begin{array}{l}0.758^{* *} \\
(0.060)\end{array}$ & 2.135 & 0.000 \\
\hline $\begin{array}{l}\text { Number of } \\
\text { Household } \\
\text { Members (V4) }\end{array}$ & $\begin{array}{l}0.175^{* *} \\
(0.032)\end{array}$ & 1.191 & 0.000 & $\begin{array}{c}0.068 \\
(0.055)\end{array}$ & 1.070 & 0.322 & $\begin{array}{l}0.322^{* *} \\
(0.054)\end{array}$ & 1.380 & 0.000 \\
\hline $\begin{array}{l}\text { Residential Area } \\
\text { (V5) }\end{array}$ & $\begin{array}{l}0.286^{* *} \\
(0.034)\end{array}$ & 1.331 & 0.000 & $\begin{array}{l}0.542^{* *} \\
(0.063)\end{array}$ & 1.720 & 0.000 & $\begin{array}{l}0.340^{* *} \\
(0.063)\end{array}$ & 1.405 & 0.000 \\
\hline N & & 19,326 & & & 6,433 & & & 8,660 & \\
\hline Pseudo R2 & & 0.0368 & & & 0.0644 & & & 0.1125 & \\
\hline$P$-value & & 0.000 & & & 0.000 & & & 0.000 & \\
\hline Goodness of Fit & & 0.818 & & & 0.117 & & & 0.379 & \\
\hline
\end{tabular}

** Significance level $a=0,05$

Source: Susenas March 2018, Statistics of Indonesia (Author's calculation)

Besides, there are also partial test results to see the relationship of each independent variable with the dependent variables. The partial test results in Maluku-Papua show that the five independent variables (household head's education, mother's education, household head's business sector, number of household members, and residential area) have p-values less 
than $\alpha=0.05$. Thus, the five independent variables statistically affect the dependent variable. Different things show in Java and Bali-Nusa Tenggara. The household head's business sector variable in Java has a p-value of 0.655 , while the number of household members variable in the Bali-Nusa Tenggara has a p-value of 0.213 . Statistically, the variable of household head's business sector in Java and the number of household members in Bali-Nusa Tenggara do not significantly influence the possibility of early childhood children suffering from absolute poverty because the $\mathrm{p}$-value is more significant than $\alpha=0.05$.

The education of the household head and the mother have a significant influence on the possibility of early childhood children suffering from absolute poverty. The three regions do not have different results in terms of the relationship between the absolute poverty status of early childhood children with the household head's education or the mother's education variables. This result can observe from the p-value smaller than $\alpha=0.05$. In all three regions, the mother's education has an odds ratio higher than the household head's education (in this study, the household head is a male). It means that mothers have a more significant role in preventing the absolute poverty of early childhood children. The higher the education of the mother, the higher the mother's awareness of the importance of fulfilling the basic needs of the children. According to research by Ferrone \& Chzhen (2016), head of household education is still the main predictor of deprivation of children in Bosnia, even after accounting for the impact of other relevant household characteristics. Children living with lower educated household heads are significantly more likely to experience deprivation in one of seven dimensions.

The business sector of the household's head variable that influences the possibility of early childhood children suffering from absolute poverty only occurs in Bali-Nusa Tenggara and Maluku-Papua. The Maluku-Papua odds ratio value is higher than Bali-Nusa Tenggara. Early childhood children who live with household heads working in the agricultural sector in Bali-Nusa Tenggara and Maluku-Papua have a higher possibility of suffering from absolute poverty than early childhood children living with household heads who work outside the agricultural sector. This fact is because households with income sources from agriculture tend to live in the restricted condition so that it will also be limited in fulfilling the basic needs of their children.

The variable of the number of household members influences the possibility of early childhood children suffering from absolute poverty only occurs in Java and Maluku-Papua. In both regions, early childhood children who live in households with more than four people have more significant opportunities than households having a maximum of 4 people. The number of household members has a positive effect on poverty. The risk of suffering from poverty will be even higher when the number of household members increases (Nopriansyah et al., 2015).

Residential Area has a significant influence on the chance of early childhood children suffering from absolute poverty. Based on the p-value that is smaller than $\alpha=0.05$, it can reveal that the three regions do not have different results on the relationship between absolute poverty status of early childhood children with the residential area variable. This condition 
means that early childhood children who live in rural households have more significant opportunities than those living in urban households. Rural areas have limited access to information, so is the knowledge of households living in rural areas about the importance of fulfilling children's basic rights.

\section{The Highest and Lowest Odds of Early Childhood Children Suffering from Absolute Poverty}

Based on Table 3, the odds ratio of children suffering from absolute poverty in Java, which has the highest value, is the variable of mother's education, which is 1.667 . This value means that the opportunity for early childhood children to suffer from absolute poverty is 1.667 times higher when the mother's education is lower or equal to junior high school compared to mothers with education higher than junior high school. From these results, it can reveal that a mother's education has a significant effect on the possibility of children suffering from poverty (Bachtiar et al., 2016; Ferrone \& Chzhen, 2016). The mother's education level influence the child's growth and development (Apriastuti, 2013). The higher the mother's education, the better will be the growth and development of the child because the mother has a good understanding of the fulfillment of the child's basic needs.

In contrast to Java, the highest odds ratio in Bali-Nusa Tenggara is the residential area variable that is equal to 1.720 . It means early childhood children have 1.720 times greater possibility of suffering from absolute poverty when living in rural areas than their counterparts living in urban areas. In their research, Bachtiar et al. (2016) stated that the opportunity for children to experience absolute poverty was 1,236 times greater when the child lived in rural areas than in urban areas. Children who live in rural areas will deprive in one higher dimension compared to children who live in urban areas (Ferrone $\&$ de Milliano, 2018).

The highest odds ratio of early childhood children suffering from absolute poverty in Maluku-Papua is the household head's business sector, which is 2.135 . The value of the odds ratio can also interpret that when the household head works in the agricultural sector, it will cause the opportunity for early childhood children suffering from absolute poverty by 2.135 times more than the household head working in other sectors. The business sector of the household head significantly affects the probability of a child suffering from poverty (Fonta et al., 2019; Adetola \& Olufemi, 2012).

The lowest odds ratio for early childhood children suffering from absolute poverty in the Bali-Nusa Tenggara is 1.429 coming from the household head's business sector variable. This value means that early childhood children are at risk of suffering from absolute poverty 1.429 times greater when the household head's business sector is in the agricultural sector compared to those who work in other sectors.

In contrast to Bali-Nusa Tenggara, the odds ratio for early childhood children suffering from absolute poverty in Java and Maluku-Papua is the number of household members valued at 1.191 and 1.380, respectively. The number of household members is the smallest opportunity for early childhood children suffering from absolute poverty in Java and Maluku-Papua when compared with the household head's education, mother's education, 
and residential area. Children with two or more siblings in the household are 2.4 times more likely to be deprived than the rest (Ferrone $\&$ Chzhen, 2016). The possibility of a child living in a household with more than four members is 2,592 times poor compared to a child living in a household that has four or fewer members (Ramadhani, 2017).

\section{Conclusion}

The percentage of early childhood children whose basic needs fulfill in each region is as follows 26.35 percent (Java), 14.85 percent (Bali-Nusa Tenggara), and 7.97 percent (MalukuPapua). Meanwhile, the percentage of early childhood who suffer from absolute poverty in each region is as follows Java (32.41 percent), Bali-Nusa Tenggara (53.77 percent), and Maluku-Papua (70.71 percent). The majority of early childhood children in the Java region deprive in 1 dimension. In contrast to the other two regions, most of the early childhood children in Bali-Nusa Tenggara and Maluku-Papua deprive in 2 dimensions. These results are still far from ideal; both Java and Non-Java still have shortcomings in terms of fulfilling the basic needs of children. This condition needs attention from both the central and regional governments so that future poverty alleviation programs do not only focus on fulfilling the needs of adults but also the basic needs of children.

The results show that the 95 percent significant level of household characteristics that affect the possibility of early childhood children suffering from absolute poverty in MalukuPapua is the household head's education, mother's education, the household head's business sector, the number of household members, and the residential area. However, in the other two regions, there are household characteristics that do not significantly affect early childhood children suffering from absolute poverty. The household head's business sector does not have any effect on the opportunity of early childhood absolute poverty in Java. The number of household members has no impact on the possibility of early childhood absolute poverty in Bali-Nusa Tenggara. The characteristics of households that have the highest possibility of affecting early childhood children suffering from absolute poverty in each region vary, such as the mother's education (Java), the residential area (Bali-Nusa Tenggara), and the household head's business sector (Maluku-Papua).

Local governments can focus more on determining policies in efforts to reduce child poverty. The action policy to reduce child poverty that the government needs to do are to improve the 12-year required education program to improve human resource quality, rural development to reduce disparity in rural and urban areas, as well as provide venture capital for farmers to improve the welfare of farmers, especially in rural areas. The three programs expect to work well so that they will have a positive impact on efforts to satisfy the basic needs of children. Each region certainly has different priorities in handling child poverty.

\section{References}

Adetola, A., \& Olufemi, P. (2012). Determinants of Child Poverty in Rural Nigeria : A Multidimensional Approach. Global Journal of Human Social Science Arts \& Humanities, 12(12), 38-54. 
Agresti, A. (2007). An Introduction to Categorical Data Analysis. New York: John Wiley \& Sons.

Alkire, S., Foster, J. E., Seth, S., Santos, M. E., Roche, J. M., \& Ballon, P. (2015). Multidimensional Poverty and Analysis: The Framework. Oxford Poverty and Human Development Initiative (OPHI) Working Paper No. 83. https://doi.org/10.1093/ acprof:oso/9780199689491.003.0002

Apriastuti, D. A. (2013). Analisis Tingkat Pendidikan Dan Pola Asuh Orang Tua dengan Perkembangan Anak Usia 48 - 60 Bulan (Analysis of The Level of Education and Parenting of Parents with Development of Children Aged 48-60 Months). Jurnal Ilmiah Kebidanan, 4(1), 1-14.

Bachtiar, N., Rasbi, M. J., \& Fahmi, R. (2016). Analisis Kemiskinan Anak Balita pada Rumah Tangga Di Provinsi Sumatera Barat (Analysis of Children Poverty in Households in West Sumatera). Kependudukan Indonesia, 11(1), 29-38.

Brooks-Gunn, J., \& Duncan, G. J. (1997). The Effects of Poverty on Children. Future of Children, 7(2), 55-71. https://doi.org/10.2307/1602387

Chou, K. L. (2013). Familial Effect on Child Poverty in Hong Kong Immigrant Families. Social Indicators Research, 113(1), 183-195. https://doi.org/10.1007/s11205-012-0088-7

Dickerson, \& Popli, G. (2017). The Many Dimensions of Child poverty : Evidence from The UK Millennium Cohort Study. Fiscal Studies, 39(2), 265-298. https://doi. org/10.1111/1475-5890.12162.

Ferrone, L., \& Chzhen, Y. (2016). Comparing Approaches to the Measurement of Multidimensional Child Poverty. Florence: Innocenti Working Paper, 29(December).

Ferrone, L., \& de Milliano, M. (2018). Multidimensional Child Poverty in Three Countries in Sub-Saharan Africa. Child Indicators Research, 11(3), 755-781. https://doi. org/10.1007/s12187-017-9487-2

Fonta, W. M., Nkwenkeu, S. F., Lath, M., Hollebecque, A., Ouedraogo, B., \& Sirajo, S. (2019). Multidimensional Poverty Assessment among Adolescent Children in the Mouhoun Region of Burkina Faso, West Africa. Child Indicators Research, 12(4), 1287-1318. https://doi.org/10.1007/s12187-018-9575-y

Fox, L., Wimer, C., Garfinkel, I., Kaushal, N., Nam, J., \& Waldfogel, J. (2015). Trends in Deep Poverty from 1968 to 2011: The Influence of Family Structure, Employment Patterns, and The Safety Net. 1(1), 14-34. https://doi.org/10.7758/rsf.2015.1.1.02

Gordon, D., Nandy, S., Pantazis, C., Pemberton, S., \& Townsend, P. (2003). Child Poverty in the Developing World. United Kingdom: The Policy Press.

Gordon, D., Irving, M., Nandy, S., \& Townsend, P. (2005). Multidimensional measures of child poverty. Working Paper. Townsend Centre for International Poverty. Retrieved from http://www.ipc-undp.org/conference/md-poverty/papers/Dave Gordon.pdf

Ifelunini, I. A., Jonah, T. A., Wosowei, E. C., \& Otene, S. (2013). Multidimensional Poverty Incidence in Nigeria : Empirical Insight from Core Welfare Indicator Questionnaire (CWIQ) Survey. Journal of Economics and Sustainable Development, 4(16), 105-113. 
Musiwa, A. S. (2019). Multidimensional Child Poverty in Zimbabwe: Extent, Risk Patterns and Implications for Policy, Practice and Research. Children and Youth Services Review, 104, 104398. https://doi.org/10.1016/j.childyouth.2019.104398

Nopriansyah, Junaidi, \& Etik Umiyati. (2015). Determinan Kemiskinan Rumah Tangga di Provinsi Jambi (Determinant of Household Poverty in Jambi). Jurnal Perspektif Pembiayaan Dan Pembangunan Daerah, 2(3), 119-128.

Pemberton, S., Gordon, D., \& Nandy, S. (2012). Child Rights, Child Survival and Child Poverty: The debate. United Kingdom: The Policy Press.

Qi, D., \& Wu, Y. (2015). A multidimensional child poverty index in China. Children and Youth Services Review, 57, 159-170. https://doi.org/10.1016/j.childyouth.2015.08.011

Ramadhani, A. W. and M. A. I. (2017). Kemiskinan Anak di Provinsi DKI Jakarta: Susenas 2017 (Child Poverty in DKI Jakarta: Susenas 2017). Jurnal Ekonomi Kuantitatif Terapan, 12 (2), 111-123.

Rochwidowati, N. S., \& Widyana, R. (2017). Peningkatan Kemandirian Anak Usia Prasekolah Dengan Pemberian Pengukuh Positif (Increased Independence of Preschoolers with Positive Reinforcement). Insight: Jurnal Ilmiah Psikologi, 18(1), 49-56. https://doi. org/10.26486/psikologi.v18i1.348

Roelen, K., \& Neubourg, C. De. (2009). False Positives or Hidden Dimensions What Can Monetary and Multidimensional Measurement Tell Us About Child Poverty? Working Papers MGSoG/2009/015. Maastricht Graduate School of Governance.

Scott, A. J., Hosmer, D. W., \& Lemeshow, S. (1991). Applied Logistic Regression. Biometrics, 47(4), 1632-1640. https://doi.org/10.2307/2532419

SMERU, \& UNICEF. (2013). Urgensi Penanggulangan Kemiskinan Multidimensi pada Anak di Indonesia (The urgency of Multidimensional Child Poverty Reduction in Indonesia). SMERU Working Paper, 3, 1-4.

Sukamti, E. R. (1994). Pengaruh Gizi Terhadap Pertumbuhan Dan Perkembangan Anak (The Effect of Nutrition on Children's Growth and Development). Cakrawala Pendidikan, 3(3), 139-153. https://doi.org/10.21831/cp.v3i3.9154 